\title{
Effect of Grazing by Cattle on the Abundance of Grasshoppers on Fescue Grassland
}

\author{
N.D. HOLMES, D.S. SMITH, AND A. JOHNSTON
}

\begin{abstract}
Grasshoppers were collected annually from 1970 to 1976 in late August from experimental fields of fescue rangeland that had been grazed by cattle at four rates of intensity. Sixteen species of grasshoppers were found but only four species constituted $90 \%$ of the population. Chorthippus longicornis, Melanoplus sanguinipes, Aeropedellus clavatus, Neopodismopsis abdominalis, and M. bivittatus were more abundant on the lightly and moderately grazed fields, whereas $M$. dawsoni, $M$. gladstoni and $M$. infantalis were more abundant in the heavily and very heavily grazed fields. Camnula pellucida was randomly distributed among the four fields. Generally, more grasshoppers were collected from the heavily and very heavily grazed fields than from the lightly and moderately grazed fields.
\end{abstract}

The distribution and abundance of various species of grasshoppers are related to the composition and density of the vegetative cover on native grasslands (Anderson 1964). Therefore, changes in the vegetative cover should result in changes in grasshopper populations. It has been demonstrated that renovations of rangeland involving contour furrowing and scalping reduced the numbers of most species of grasshoppers in a test area (Hewitt and Rees 1974). Anderson (1964) has suggested that grazing practices may affect the abundance of grasshoppers, and Bird (1961) postulated that overgrazing by buffalo created an environment that favored outbreaks of grasshoppers in the plains area. A general review of the subject has been recently published by Hewitt (1977).

The study reported here was initiated to determine if different intensities of grazing affect the densities of various species of grasshoppers on native fescue rangeland. An experimental area in the foothills of southern Alberta on which controlled intensities of grazing by cattle had been applied for 19 years provided a unique opportunity for this work.

\section{Materials and Methods}

The study was done from 1970 to 1976 on four fields at the Stavely Range Research Substation located on a fescue grassland range 100 $\mathrm{km}$ northwest of Lethbridge, Alta.

Each of the fields had been grazed since 1951 at one of four intensities: light $-0.8 \mathrm{ha} / \mathrm{animal}$ unit/month; moderate $-0.6 \mathrm{ha} / \mathrm{ani}-$ mal unit/month; heavy $-0.4 \mathrm{ha} /$ animal unit/month; and very heavy-

N.D. Holmes and A. Johnston are entomologist and range ecologist, respectively. Rescarch Station, Agriculture Canada. Lethbridge. Alberta. Canada TIJ 4B I; D.S. Smith is entomologist. now retired from Research Station. Agriculture Canada, Lethbridge.

Manuscript received June 28.1978 .
0.2 ha/animal unit/month (Johnston et al. 1971). The grasshoppers on each of the four fields were sampled in late August each year with 100 sweeps of a standard insect net, except in 1974 and 1975 when 50 sweeps were taken. The samples, which were brought into the laboratory for idéntification and enumeration, are reported on the basis of 50 sweeps per field.

The relative frequencics of the components of the vegetation in the four fields and the yields of these components, which had been measured before the start of this experiment (Johnston et al. 1971), were measured again in 1977.

\section{Results and Discussion}

The progressive increases in rates of intensity of grazing progressively decreased the area covered by grasses, increased the area covered by forbs, but had no effect on the sedges among the four experimental fields. Very heavy grazing created a drier microclimate with increased soil temperature and decreased soil moisture (Johnston et al. 1971). Measurements in 1977 confirmed that the average percentage composition and basal area and yield of various components of the vegetation reflected the grazing treatments. The dominant grass, Festuca scabrella Torr., decreased as grazing intensity increased. Similarly, the amounts of grasses, forbs and shrubs, and litter decreased as intensity of grazing increased. Grazing produced a lowergrowing type of cover that was less dense than on the lightly grazed fields. The total above-ground vegetal biomass was lowest on the very heavily grazed field; the lightly grazed field produced $1,671 \mathrm{~kg} / \mathrm{ha}$ of vegetation and $1,864 \mathrm{~kg} / \mathrm{ha}$ of litter compared to $82 \mathrm{~kg} / \mathrm{ha}$ of vegetation and no litter from the very heavily grazed field.

Sixteen species of grasshoppers were found but only the most common are listed in Table 1. Other species found were Encoptolophus sordidus (Scudder), Melanoplus bruneri Scudder, M. foedus Scudder, M. oregonensis (Thomas), Opeia obscura (Thomas), Psoleossa delicatula (Scudder), and Xanthippus sp.

Of the four species that constituted $90 \%$ of the population, Melanoplus dawsoni was more prevalent every year on the heavily and very heavily grazed fields, whereas Chorthippus longicornis, every year, and M. sanguinipes, except in 1972, were more abundant on the lightly and moderately grazed fields (Table 1). Camnula pellucida appeared to be randomly distributed among the four fields.

The responses of the different species of grasshoppers to the changes in vegetative cover appear to be related to their food and 
Table 1. Mean numbers of grasshoppers per 50 sweeps on fields at Stavely Substation subjected to four rates of grazing, 1970-76.

\begin{tabular}{|c|c|c|c|c|c|}
\hline \multirow[b]{2}{*}{ Species of grasshopper } & \multicolumn{4}{|c|}{ Intensity of grazing of field } & \multirow[b]{2}{*}{ Mean } \\
\hline & Light & Moderate & Heavy & $\begin{array}{l}\text { Very } \\
\text { heavy }\end{array}$ & \\
\hline $\begin{array}{l}\text { Melanoplus dawsoni } \\
\text { (Scudder) }\end{array}$ & 46.6 & 52.4 & 90.0 & 132.0 & 80.3 \\
\hline $\begin{array}{l}\text { Chorthippus longicornis } \\
\text { (Latr.) }\end{array}$ & 61.9 & 47.0 & 40.6 & 23.0 & 43.1 \\
\hline $\begin{array}{l}\text { Camnula pellucida } \\
\text { (Scudder) }\end{array}$ & 18.9 & 14.6 & 18.7 & 27.7 & 20.0 \\
\hline Melanoplus sanguinipes (F.) & 14.0 & 9.0 & 1.7 & 6.1 & 7.7 \\
\hline M. gladstoni Scudder & 2.9 & 3.4 & 4.6 & 8.4 & 4.8 \\
\hline M. bivittatus (Say) & 3.0 & 4.7 & 2.1 & 2.3 & 3.0 \\
\hline $\begin{array}{l}\text { Neopodismopsis abdominalis } \\
\text { (Thomas) }\end{array}$ & 4.9 & 2.0 & 3.0 & 1.0 & 2.7 \\
\hline M. infantalis Scudder & 1.3 & 1.6 & 0.7 & 5.1 & 2.2 \\
\hline $\begin{array}{l}\text { Aeropedellus clavatus } \\
\text { (Thomas) }\end{array}$ & $\begin{array}{r}1.0 \\
154.5\end{array}$ & $\begin{array}{r}3.3 \\
138.0\end{array}$ & $\begin{array}{r}0.4 \\
161.8\end{array}$ & $\begin{array}{r}1.0 \\
206.6\end{array}$ & 1.4 \\
\hline
\end{tabular}

habitat preferences. $M$. dawsoni is primarily a forb feeder, $C$. longicornis feeds on grasses and sedges, $M$. sanguinipes is a mixed feeder with a preference for forbs, and Camnula pellucida is a grass and sedge feeder that readily eats forbs (Brooks 1958). Anderson (1964) found $M$. daw'soni to be most prevalent on fields with low percentage foliage cover and $C$. pellucida to be most abundant on fields with a $21-60 \%$ perennial grass cover.

Melanoplus gladstoni and $M$. infantalis, which were most prevalent on the heavily grazed field, are general mixed feeders (Brooks 1958). M. gladstoni was one of the few species found to be unaffected by scalping rangeland (Hewitt and Rees 1974) and $M$. infantalis occurred most frequently on sites with less than 20\% foliage cover (Anderson 1964).

Neopodismopsis abdominalis was most abundant on the lightly grazed field and Aeropedellus clavatus was most abundant on the moderately grazed field. Both feed on grasses and sedges (Brooks 1958). Melanoplus bivittatus, which was also most abundant on the moderately grazed field although it was common on the other fields, is a general feeder that prefers forbs (Brooks 1958).

Despite the decreases in numbers of $C$. longicornis and $M$. sanguinipes caused by the heavier rates of grazing, the increases in numbers of $M$. dawsoni in particular were enough to produce higher total numbers of grasshoppers on the heavily and very heavily grazed fields than on the lightly and moderately grazed fields in 5 of the 7 years (Table 1). Similar results were obtained in studies in Oklahoma and Kansas where it was shown that grasshoppers were generally more abundant on heavily grazed pastures than on lightly grazed ones (Smith 1940; Campbell et al. 1974).

Increased intensity of grazing progressively reduced the amounts of vegetation available for consumption by grasshoppers. In the 1950-67 period, the cattle utilized 20, 50, 70, and $90 \%$ of the forage from the lightly, moderately, heavily, and very heavily grazed fields (Johnston et al. 1971). At the end of the growing season in 1977, the weights of vegetation, including litter left on the moderately, heavily, and very heavily grazed fields were $28.8,18.5$, and $2.4 \%$ of the left on the lightly grazed field. Thus, increased competition by grasshoppers for forage could result from increased grazing even if the numbers of grasshoppers remain constant or even decrease. Nerney (1958) has reported that a population of 15 grasshoppers/yd $\mathrm{y}^{2}$ $\left(17.9 / \mathrm{m}^{2}\right)$ ate $20 \%$ of the herbage on a moderately grazed pasture and $70 \%$ of that on a heavily grazed one. As the decreased amounts of forage on the heavily and very heavily grazed fields at Stavely were combined with increased numbers of grasshoppers, it appears that the economic effects could have been compounded by the heavier rates of grazing.

Conclusions concerning the losses incurred, however, cannot be drawn from the present study, which was undertaken only to determine if grazing affected grasshopper populations. Such conclusions would require a detailed examination of the amounts and kinds of vegetation eaten by the species of grasshoppers involved as well as periodic samples taken during the growing season to account for early hatching species that may be absent after mid-July.

\section{Conclusions}

Changes in the microhabitat caused by varying intensities of grazing by cattle had major effects on the grasshopper population on a fescue rangeland. Increased intensity of grazing decreased the numbers of some species of grasshoppers, and increased the abundance of others. One species of grasshopper, which was apparently more widely adaptable than others, was unaffected. The change in the vegetative cover caused by the heaviest rates of grazing resulted in increased total numbers of grasshoppers in most years.

\section{Literature Cited}

Anderson, N.L. 1964. Some relationships between grasshoppers and vegetation. Ann. Entomol. Soc. Amer. 57: 736-742.

Bird, R.D. 1961. Ecology of the aspen parkland. Can. Dep. Agr. Pub. 1066. $155 \mathrm{p}$.

Brooks, A.R. 1958. Acridoidea of southern Alberta. Saskatchewan. and Manitoba (Orthopetra). Can. Entomol. Suppl. 9. 92 p.

Campbell, J.B., W.H. Arnett, J.D. Lambley, O.K. Jantz, and H. Knutson. 1974. Grasshoppers (Acrididae) of the Flint Hills native tall grass prairie in Kansas. Kansas State. Exp. Sta., Res. Pap. 19. 147 p.

Hewitt, G.B. 1977. Review of forage losses caused by rangeland grasshoppers. U.S. Dep. Agr., Agr. Res. Serv. Misc. Publ. 1348.

Hewitt, G.B., and N.E. Rees. 1974. Abundance of grasshoppers in relation to rangeland renovation practices. J. Range Manage. 27:156-160.

Johnston, A., J.F. Dormaar, and S. Smoliak. 1971. Long-term grazing effects on fescue grassland soils. J. Range Manage. 24:185-188.

Nerney, N.J. 1958. Grasshopper infestations in relation to range condition. J. Range Manage. 11:247.

Smith, C.C. 1940. The effect of overgrazing and erosion upon the biota of the mixed grass prairie of Oklahoma. Ecology 21:381-397.

\section{Moving?}

Please let us know your new address. Send address

changes to:

Society for Range management

2760 West Fifth Avenue

Denver, Colo. 80204 